\title{
Kromdraai evolved, but poorly packaged
}

\section{BOOK TITLE:}

Kromdraai: A birthplace of Paranthropus in the Cradle of Humankind

\section{BOOK COVER:}

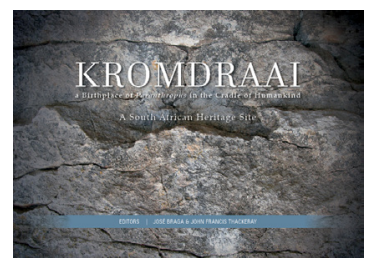

EDITORS:

José Braga and

J. Francis Thackeray

ISBN:

9781928355069 (hardcover)

PUBLISHER:

SUN Press, Stellenbosch; ZAR340

\section{PUBLISHED:}

2016

\section{REVIEWER:}

Andy I.R. Herries ${ }^{1,2}$

\section{AFFILIATIONS:}

${ }^{1}$ Department of Archaeology and History, College of Arts, Social Science and Commerce, La Trobe University, Melbourne, Australia

${ }^{2}$ Centre for Anthropological Research, University of Johannesburg, Johannesburg, South Africa

\section{EMAIL:}

A.Herries@latrobe.edu.au

\section{HOW TO CITE:}

Herries AIR. Kromdraai evolved, but poorly packaged. S Afr J Sci. 2018;114(1/2), Art. \#a0241, 2 pages. http://dx.doi. org/10.17159/sajs.2018/a0241

(C) 2018. The Author(s). Published under a Creative Commons Attribution Licence.
The Kromdraai Palaeocave System has been of interest to palaeoanthropology since Robert Broom's identification of the type specimen of Paranthropus robustus (TM1517) in 1938. ${ }^{\text {It }}$ is one of the classic homininbearing sites of South Africa and has been excavated by a number of iconic South African scientists including Bob Brain in the 1950s, and Elizabeth Vrba in the 1970s and 1980s. However, so little published work has come from the site. Since 2002, the work at the site has been directed by José Braga and Francis Thackeray (the latter also excavating in the 1990s) as part of a joint French-South African collaboration, and they have brought their recent research together in a new book: Kromdraai: A birthplace of Paranthropus in the Cradle of Humankind ${ }^{2}$. It is an odd book in the sense that when it arrived it looked like it was going to be a more popular science book, more akin to Ron Clarke and Tim Partridge's Caves of the Ape-Men ${ }^{3}$. The cover artwork also does nothing to portray the subject matter within, as it is simply a picture of mossy covered dolomite. However, in opening the book you come to the realisation that it is actually an edited volume of scientific articles packaged in an odd, rectangular, coffee-table format. In part this is probably a reflection of the relatively new (2003), pay-to-publish publisher chosen by the authors, African Sun Media. The nature of this type of publishing bleeds through the book in other ways in that there are both excellently reproduced photos and figures in some instances, but poor-quality, blurry figures in others - most notably one of the most important in the book, Figure 3.1, which shows the new plan of the stratigraphy of the site. It does make you wonder why the authors chose this format of publishing for research that could have been published in higher impact, and critically for the South African market, open access journals.

With regard to the science presented, the book covers the history of research at the site; some very interesting new research using 3D scanning and photogrammetry; an important revised stratigraphy; a paper on the hominin material including valuable work using the enamel-dentine junction for identifying different species; and a preliminary analysis of the fauna excavated from the oldest fossil deposit at the site, Member 2. Chapter 2, which covers the $3 \mathrm{D}$ mapping and visualisation of the site is perhaps the one that stands out as a good example of new types of research being undertaken on these old sites, although it is research that is now regularly being undertaken at such sites. ${ }^{4,5}$ Here the different scales of this type of analysis do stand as different from what has been published to date, although a journal format with its ability to have online content, such as videos, may have been a better format to showcase these 3D models.

The stratigraphy chapter by Bruxelles et al. on Kromdraai B (as disappointingly the faunal site Kromdraai A is really not dealt with) is also an important piece of research that fundamentally shows the complexity of this site. In many ways, it also suggests that the research at the site needs to simply start from scratch, because the vast majority of fossils excavated from the site have very uncertain to unknown provenience. It is a sentiment that is being increasingly echoed about the early sites that have been excavated or sampled for over 70 years. In another way, it is a rather transformative chapter for the site as well, because it changes the perception from that of Kromdraai as a small site that had been pretty much exhausted, with all the fossils coming from a single deposit, to that of a massive site with great future potential. The new excavations have both expanded the lateral extent of the site as well as its depth, with a hint that much older Australopithecus-bearing deposits may be buried below. Here the reader is, in some sense, presented with a vision that is truly different from that presented by Partridge ${ }^{6,7}$ on the stratigraphy of the site, but in other senses (in continuing to follow a Member system), the vision is perhaps not revolutionary enough. What it does do, although not an intentional aim of the research, is to lay bare the problems of the numbered Member system used at all these sites. Namely, what do you do when you find a new deposit between Member 2 and 5 ? Here Bruxelles et al. have opted to create numbered sub-Member units (4.1-4.3). This creates an ultra-confusing renaming convention whereby parts of Member 3 remain Member 3, and other parts of Member 3 become 4.1. Member 4 becomes 4.2, Member 5 becomes 4.3 and Members 1-3 of the previously defined KB West formation become Members 5-7. Thankfully they have a nice table to illustrate these changes.

The next issues that will come with the Member system of the site is when dates are given to these various Members and sub-Members and they are perhaps found to not be in this stratigraphic order, or, as shown for other sites ${ }^{8}$, some of the Members are contemporary with each other. The lack of chronometric dates is certainly the most absent piece of research from the volume. The same potential problem exists for this Member system as the original, in that defining sedimentologically distinct Members is not defining a chronostratigraphy, and very different looking sedimentological deposits can form at the same time in different parts of the same cavern and system. Only time will tell how accurate this new stratigraphy is, but the way it is presented with numerous sections through the deposit described and illustrated is a very useful reference for any future work at the site. This is perhaps an example of a paper with great value that might not have been suitable for a journal format. It is the pure descriptive science that is needed to conduct research and provide a legacy record of a site, but work which sadly many journals seem unprepared to publish these days because the information is deemed of 'only local interest' or 'limited impact'. Yet this is exactly the type of primary research that needs to be published, so that we can fully understand what was done at the sites, and how they were interpreted when 2017 is as long ago as 1938 is today. What this chapter also does is lay bare one of the truly fundamental outcomes of this book - that we will likely never know the exact provenience, and thus age, of the type specimen of Paranthropus robustus.

In contrast to this geology chapter, the faunal chapter is instead rather devoid of actual data and its formatting has not been homogenised between different taxonomic groups, which I assume is a reflection of different author styles. Very few photos of the material being described are presented and in some cases only a species list is presented with no primary descriptions or metrics. In such situations, which is becoming all too common in palaeontological papers, the reader has to take the authors' word for the existence of a species as no actual data are presented. A species list with no primary descriptions and evidence of what the fossils were compared to, is 
like stating the answer is 42 , without any maths calculations showing how the number was obtained. In terms of the science, the book is thus a mixed bag.

On the cover page, it is stated: 'The publication was subjected to an independent double-blind peer evaluation by the publisher.' Given the various issues in the book with regard to the formatting, language and science, what exactly does this mean? The book would have benefitted from a thorough proofreading, as there are grammatical and spelling errors throughout. These errors give the impression that the contents were not vetted particularly thoroughly by the reviewers. In a time when there is a dramatic rise in anti-science (such as the number of people who actually believe the earth is flat), when the very nature of peer review is under threat from a proliferation of for-profit journals, and when research funding is becoming increasingly difficult to obtain, it is not an unreasonable question to ask where such pay-to-publish books sit within academia and our evaluation of a scientist's work. Is it, as in the model adopted by some open access journals, now a case of scientists publishing their unhindered views of the record, with peer review simply coming from widespread popular analysis of its quality after the fact? Certainly, in a time when there is a push towards publishing data from research to combat the 'reproducibility crisis' in science', this book feels, at best, somewhat old school, and, at worst, a result of a method of publishing that allows the authors to present the story they choose without hindrance.

This lack of thorough reviewing comes through in other ways, as the story presented suggests a distinct 'cherry picking' of certain papers and data to present a particular story of the South African record. This is most notable in the poor and biased referencing of current research, especially regional chronology. For example, citing the McKee et al. ${ }^{10}$ faunal seriation paper as evidence for the age of Makapansgat, Taung and Sterkfontein in 2016, but none of the chronometric studies undertaken in the last 10 years $^{8}$ or so is one such example. The understanding of local chronology is based purely on cosmogenic nuclide burial dating; although citing Granger et al. ${ }^{11}$ for the age of Australopithecus africanus at Sterkfontein at 3.0-2.6 Ma is odd in that it is a study dating the Member 2 Stw573 deposits and Member 5, not the Member 4 deposit from which $\mathrm{Au}$. africanus has primarily been recovered. Chronometric studies actually put this deposit at 2.6-2.0 Ma based on a combination of electron spin resonance, uranium-lead and palaeomagnetic dating. ${ }^{8}$

There is some truly fascinating new research that transforms our idea of what the site may represent and yield, but the sloppy nature of the reviewing, publication, writing and formatting, means that many readers will not come away trusting the information presented, rightly or wrongly, in the same way they do similar books such as Brain's 1993 Swartkrans: A Cave's Chronicle of Early Man ${ }^{12}$. Nonetheless, as Bob Brain states in the Foreward to the book, it is a delight to see how the Kromdraai Research Project is changing our understanding of the Kromdraai deposits and its hominins through these mostly very preliminary findings. I personally cannot wait to see what future work at the site will yield.

\section{References}

1. Broom R. The Pleistocene anthropoid apes of South Africa. Nature. 1938;142:377-379. https://doi.org/10.1038/142377a0

2. Braga J, Thackeray JF. Kromdraai: A birthplace of Paranthropus in the Cradle of Humankind. Stellenbosch: SUN Press; 2016. https://doi. org/10.18820/9781928355076

3. Clarke R, Partridge T. Caves of the ape-men: South Africa's Cradle of Humankind World Heritage Site. Johannesburg: Wits University Press; 2010.

4. Kruger A, Randolph-Quinney PS, Elliott M. Multimodal spatial mapping and visualisation of Dinaledi Chamber and Rising Star Cave. S Afr J Sci. 2016;112(5/6), Art. \#2016-0032, 11 pages. https://doi.org/10.17159/ sajs.2016/20160032

5. Armstrong B, Blackwood A, Penzo-Kajewski P, Menter C, Herries AIR. Terrestrial laser scanning and photogrammetry techniques for documenting fossil bearing palaeokarst with an example from the Drimolen Palaeocave System, South Africa. Archaeol Prospect. In press 2017. https://doi. org/10.1002/arp.1580

6. Partridge TC. Some preliminary observations on the stratigraphy and sedimentology of the Kromdraai B hominid site. In: Coetzee JA, Van Zinderen Bakker EM, editors. Palaeoecology of Africa and the surrounding islands. Vol. 15. New York: CRC Press; 1982. p. 3-12.

7. Partridge TC. Hominid-bearing cave and tufa deposits. In: Partridge TC, Maud RR, editors. The Cenozoic of southern Africa. New York: Oxford University Press; 2000. p. 100-125.

8. Herries AIR, Pickering R, Adams JW, Curnoe D, Warr G, Latham AG, et al. A multi-disciplinary perspective on the age of Australopithecus in southern Africa. In: Reed KE, Fleagle JG, Leakey R, editors. Paleobiology of Australopithecus. Vertebrate Paleobiology and Paleoanthropology Series. Dordrecht: Springer; 2013. p. 21-40. https://doi.org/10.1007/978-94-0075919-0_3

9. Marwick B, Jacobs Z. Here's the three-pronged approach we're using in our own research to tackle the reproducibility issue. The Conversation. 2017 July 19; Science and Technology. Available from: https://theconversation.com/ heres-the-three-pronged-approach-were-using-in-our-own-research-totackle-the-reproducibility-issue-80997

10. McKee J, Thackeray JF, Berger LR. Faunal assemblage seriation of southern African Pliocene and Pleistocene fossil deposits. Am J Phys Anthropol. 1995;96:235-250. https://doi.org/10.1002/ajpa.1330960303

11. Granger DE, Gibbon RJ, Kuman K, Clarke RJ, Bruxelles L, Caffee MW. New cosmogenic burial ages for Sterkfontein Member 2 Australopithecus and Member 5 Oldowan. Nature. 2015;522:85-88. https://doi.org/10.1038/ nature 14268

12. Brain CK. Swartkrans: A cave's chronicle of early man. Pretoria: Transvaal Museum; 1993. 